\author{
Jerzy Rottermund ${ }^{1}$ \\ Andrzej Knapik ${ }^{2}$ \\ Edward Saulicz $z^{3,4}$ \\ Andrzej Myśliwiec ${ }^{3}$ \\ Mariola Saulicz $z^{3,4}$ \\ Katarzyna Anna Rygiel 5 \\ Paweł Linek
}

\title{
BACK AND NECK PAIN AMONG SCHOOL TEACHERS IN POLAND AND ITS CORRELATIONS WITH PHYSICAL ACTIVITY
}

\author{
BÓL PLECÓW I SZYI WŚRÓD NAUCZYCIELI SZKÓŁ W POLSCE I JEGO ZWIĄZEK Z AKTYWNOŚCIĄ FIZYCZNĄ
}

\author{
${ }^{1}$ The School of Administration / Wyższa Szkoła Administracji w Bielsku-Białej, Bielsko-Biała, Poland \\ Department of Physiotherapy / Wydział Fizjoterapii \\ ${ }^{2}$ Silesian Medical University / Śląski Uniwersytet Medyczny w Katowicach, Katowice, Poland \\ School of Health Sciences / Wydział Nauk o Zdrowiu \\ ${ }^{3}$ The Jerzy Kukuczka Academy of Physical Education / Akademia Wychowania Fizycznego im. Jerzego Kukuczki w Katowicach, \\ Katowice, Poland \\ Department of Kinesitherapy and Special Methods of Physiotherapy / Katedra Kinezyterapii i Metod Specjalnych Fizjoterapii \\ ${ }^{4}$ The Academy of Business / Wyższa Szkoła Biznesu, Dąbrowa Górnicza, Poland \\ ${ }^{5}$ Silesian Medical University / Śląski Uniwersytet Medyczny w Katowicach, Zabrze, Poland \\ Department of Family Medicine / Wydział Medycyny Rodzinnej
}

\begin{abstract}
Background: Back pain represents one of the most common diseases across various populations of workers worldwide. This study analyzes the prevalence and severity of back pain, based on selected demographic variables, and the relationship with physical activity among school teachers. Material and Methods: The study included 998 professionally active teachers (840 females and 158 males) from the southern part of Poland. Validated psychometric tools, namely: 1) for evaluation of disability due to back pain - a Polish version of the Oswestry Disability Index (ODI) and Neck Disability Index (NDI), 2) for physical activity assessment - the Subjective Experience of Work Load (SEWL) as well as the authors' supplementary questionnaire, addressing demographic and anthropometric variables were used. Results: There was no correlation between age and the NDI scores in females $(r=0.027)$, in contrast to males $(r=0.202 ; p \leq 0.05)$. Statistically significant correlations $(p \leq 0.05)$ were reported between: age and the ODI, in both females $(r=0.219)$ and males $(r=0.180)$. No associations between the body mass index (BMI)-ODI, and BMI-NDI were found. In the case of women, disability related to low back pain (LBP) had a negative impact on the indicators of their activity during work, sports, and leisure time. In the case of men, the NDI and ODI scores did not differ, based on activity indicators. Conclusions: Our findings confirm that back pain represents a serious concern among teachers. Age appears to be a prognostic factor, while no association between the BMI and LBP has been revealed. The limitation of physical activity leads to more frequent back pain. Med Pr 2015;66(6):771-778
\end{abstract}

Key words: physical activity, teachers, back pain, neck pain, Neck Disability Index (NDI), Oswestry Disability Index (ODI)

\section{STRESZCZENIE}

Wstęp: Ból pleców to na całym świecie jedna z najczęściej spotykanych dolegliwości zdrowotnych w różnych populacjach pracowników. Celem badania była ocena występowania i nasilenia dolegliwości bólowych pleców wśród nauczycieli polskich szkół w powiązaniu $\mathrm{z}$ ich aktywnością fizyczną i zebranymi zmiennymi demograficznymi. Materiał i metody: W badaniu uczestniczyło 998 czynnych zawodowo nauczycieli (840 kobiet, 158 mężczyzn) z południowej Polski. Wykorzystano nastepujace narzędzia psychometryczne: 1) do oceny niepełnosprawności z powodu bólu pleców - polską wersję wskaźnika niepełnosprawności Oswestry (Oswestry Disability Index - ODI) i szyjny indeks niepełnosprawności (Neck Disability Index - NDI), 2) do oceny aktywności fizycznej - subiektywną ocenę wykonywanej pracy (Subjective Experience of Work Load - SEWL) oraz autorski kwestionariusz z pytaniami dotyczącymi zmiennych demograficznych i antropometrycznych. Wyniki: Nie wykazano zależności między wiekiem a NDI w grupie kobiet $(\mathrm{r}=0,027)$, w przeciwieństwie do mężczyzn $(\mathrm{r}=0,202 ; \mathrm{p} \leq 0,05)$. Różnice istotne statystycznie $(\mathrm{p} \leq 0,05)$ uzyskano między zmiennymi: wiek i ODI (u kobiet: $r=0,219$, u mężczyzn: $r=0,180)$. Nie wykazano istotności statystycznej między wskaźnikiem masy ciała (body mass index - BMI) a ODI ani między BMI a NDI. U kobiet z dolegliwościami bólowymi kręgosłupa stwierdzono niski poziom aktywności fizycznej w czasie pracy, w trakcie uprawiania sportu i spędzania wolnego czasu, natomiast u mężczyzn nie odnotowano takiej zależności. Wnioski: Uzyskane wyniki potwierdzają, że ból pleców jest poważnym problemem wśród nauczycieli. Wiek jest czynnikiem prognostycznym, natomiast nie odnotowano związku 
między BMI a bólami kręgosłupa. Ograniczenie aktywności ruchowej wiąże się z częstszymi dolegliwościami bólowymi kręgosłupa. Istnieje potrzeba wdrażania wśród nauczycieli programu promocji zdrowego stylu życia, ze szczególnym uwzględnieniem aktywności ruchowej. Med. Pr. 2015;66(6):771-778

Słowa kluczowe: aktywność fizyczna, nauczyciele, ból pleców, ból szyi, szyjny indeks niepełnosprawności (NDI), wskaźnik niepełnosprawności Oswestry (ODI)

Corresponding author / Autor do korespondencji: Paweł Linek, The Jerzy Kukuczka Academy of Physical Education in Katowice, Department of Kinesitherapy and Special Methods in Physiotherapy,

Mikołowska 72B, 40-065 Katowice, Poland, e-mail: linek.fizjoterapia@vp.pl

Received: October 11, 2014, accepted: April 17, 2015

\section{INTRODUCTION}

Back and/or neck pain is a typical modern disorder and the causes of this disease of affluence are believed to be the limitation or its physical activity, weight-bearing muscles weakness, unhealthy lifestyle and rest as well as incorrect ergonomic positions while performing professional work. In addition to the predominant role of cardiovascular diseases, some musculoskeletal disorders, including back problems, have recently started to become a leading problem worldwide. Due to a diversified and complex aetiology of these disorders, according to epidemiological criteria, they should not be treated in terms of specific diagnostic categories but rather as syndromes, containing a collection of symptoms, with a dominating sensation of pain. The problem of back and neck pain is related to all populations, across various occupational groups, and its scale is estimated to affect approximately 50\% of the adult population [1]. According to the data recorded by the European Agency for Safety and Health at Work, nearly $24 \%$ of employees from the European Union - 25 countries complain about the back pain [2].

In addition to lowering the quality of life, highly prevalent back pain disorders represent a serious economical burden. For instance, in Poland in 2013, they caused about $15 \%$ of the absence from the work in the case of men, and $10 \%$ in the case of women. Radiculopathy and neural plexus disorders were classified as the first cause of the longest absence from the work among men $(8.5 \%$ of the total sick days taken from the work by men), while other disc diseases and degenerative lesions of the vertebral spine were the third and fourth cause of absence from the work (3\% and 2.8\%, respectively). Among women, radiculopathy and neural plexus disorders were the cause of $4.7 \%$ of the total sick days taken from the work, and were the second cause in the ranking of diagnostic categories / disease items, resulting in the inability to work / disability in the context of the number of absent days, due to sickness. In the first half of the year 2014, back pain was represented by $12.4 \%$ of the total sick days taken from the work [3].

The data highlighted above indicates the need for the continuous monitoring of this problem, including particular occupational groups. The results of the research indicate different correlations between the physical activity and the back pain. However, the prevailing view is that for those who are physically active, low back pain (LBP) occurs less frequently than for those who lead more passive lifestyle [4]. Based on our review of literature, there is a lack of research on this topic among teachers but it has to be highlighted that the nature of teachers' physical activity somehow predisposes them to the problems with the back or neck pain. Moreover, the studies that have been conducted so far amongst polish teachers indicate that those teachers do not take the effort to care about their health [5]. Due to a large number of teachers (in 2013 almost 662 thousand were employed) [6], and because of their educational and social role, which is additionally connected with promotion of the healthy lifestyle, a diagnosis of the back and neck pain disorders in this professional group is of great importance.

School teachers have a lot of occasions to exhibit faulty, non-ergonomic body posture - e.g., working with a computer, correcting students' works or studying literature - which in time may lead to overused musculoskeletal system resulting in processes that may potentially cause the pain in cervical and/or lumbar region. Therefore, the aim of this study is to analyse the prevalence and severity of the back and neck pain, based on the selected demographic variables, and its relationship with physical activity among teachers. Those studies were focused on relationships between the back and neck pain, physical activity, and other demographic variables amongst the teachers. 


\section{MATERIAL AND METHODS}

\section{Study population}

The study included 998 teachers: 840 females (mean age: $38.5 \pm 9.1$ years, median: 39 years; mean body mass index (BMI): 23.4 \pm 3.5 , median: 22.8) and 158 males (mean age: $40.0 \pm 10.2$ years, median: 39 years; mean BMI: 25.6 \pm 3.5 , median: 25.2). Participants included in the study were professionally active teachers of elementary and high schools as well as of special education facilities. Between September and December 2013, 53 schools were selected at random out of 652 major public or private schools in the Regions of Bielsko-Bialskie, Cieszyńskie and Żywieckie Regions in Southern Poland.

A written agreement was obtained from the Office of Education in Bielsko-Biała, Poland (a central town of the regions where the schools were located). This research study was also approved by the Ethics Committee of the Medical University of Silesia, Katowice, Poland (KNW/0022/KB/38/14). Each teacher in the chosen schools was given a consent letter and a description of the procedures of this study, and its objectives. All the participating teachers signed their informed consent forms, including a permission to use the data for research purposes. From selected schools, we gained $71 \%$ duly completed questionnaires which were included in the study.

\section{Outcome measures}

The study has a cross-sectional design. Validated psychometric tools supplemented by the authors' questionnaire (containing demographic data on sex and age, and anthropometric characteristics - body mass and height based on which the body mass index (BMI) was calculated, according to the formula: weight $(\mathrm{kg}) /$ height $\left(\mathrm{m}^{2}\right)$; normal weight was defined as a BMI of $18.5-24.9 \mathrm{~kg} / \mathrm{m}^{2}$, overweight as BMI $=25-29.9 \mathrm{~kg} / \mathrm{m}^{2}$, and I class obesity as BMI $\left.=30-34.9 \mathrm{~kg} / \mathrm{m}^{2}\right)$. Disability of the participants, due to back pain (disability) was evaluated, using a Polish version of the Neck Disability Index (NDI) for the cervical spine, and the Oswestry Disability Index (ODI) for the lumbar spine. Habitual physical activity was assessed using the subjective experience of work load (SEWL), that is a short questionnaire used for the purpose of epidemiological studies.

The NDI questionnaire is designed to determine the respondent's degree of pain perception in the cervical spine area [7]. It contains 60 items, grouped in $10 \mathrm{sec}-$ tions, related to various domains of life (6 items per each section). Items marked by respondents are scored on a patient-specific functional scale $0-5$, according to the increase in pain sensation, and related limitations. A degree of disability due to back pain is assessed by a summary score of all the listed items (maximal possible score equals 50 ). There are intervals which classify the respondents in 5 domains - from the lack of dysfunction in a particular spinal area, to a total disability; as follows: the lack of dysfunction ( $0-4$ points), mild degree (5-14 points), moderate (15-24 points), severe (25-34 points), total disability ( $\geq 35$ points). The reliability and construct validity of the NDI tool have been verified extensively $[7,8]$. The literature review by Murphy and Lopez indicates that the NDI is the most useful instrument for neck pain patients [9]. This questionnaire was about the present condition of the cervical spine.

According to a similar concept and construction, in the ODI questionnaire, for the lumbar spine, the respondents also mark their chosen items, grouped in 10 sections (6 items per each section), which are scored on a scale $0-5$. A sum of all the points is multiplied by 2 ; this represents a disability percentage. Subsequent interpretation of these calculated scores contains 5 ranges: from minimal to total disability, as follows: $<20 \%$, minimal; $21-40 \%$, moderate; $41-60 \%$, moderate to serious; $61-80 \%$, serious; and $81-100 \%$, very serious or total disability $[10,11]$.

Similarly to the NDI, in this case the review of the literature by Murphy and Lopez also emphasizes the usefulness of the ODI for patients with the LBP [9]. However, in the ODI questionnaire the respondents were asked if they remember to have any LBP lasting for at least 3 months during a 12-month period preceding the examination.

The SEWL questionnaire serves as a tool to estimate a level of physical activity, and has been used in population studies. It includes 3 domains of activity: at work, in sports, and during leisure time (excluding sports). The summary score of physical activity in these domains is an indicator of the global physical activity of an individual. In this questionnaire, 'closed' questions were mostly used, except for those related to details of performed occupation and sports, in which the answers (based on provided examples) corresponded with the intensity level of a given activity. Respondents mark one out of 5 answers for each of the listed questions regarding the performed activities, and their answers are scored on a scale 1-5, based on the intensity level of physical activity.

An activity index is an average score of points, relevant to a given activity domain. A maximal (theoreti- 
cal) possible score is 5 - both in work activity (work indicator, WI) and in the leisure-time domain (leisure-time indicator, LTI). The highest possible score on the sport indicator (SI) is 7.4 points, which gives a maximal theoretical value of the summary indicator of 22.4 points for habitual physical activity (HPA) [12]. Philippaerts et al. highlighted that the SEWL questionnaire was superior in large-scale studies because of its simplicity [13]. Thus, this is the reason why this research tool was used in this publication to examine the large-scale occupational group of school teachers.

\section{Statistical analysis}

Descriptive statistics, including calculations of the means, medians, standard deviations (SD) of demographic and anthropometric variables were performed, using the program STATISTICA version 10.0. Comparisons of percentage data were made by calculating differences between the 2 structure indexes. Relationships between the age and BMI, and ODI and NDI questionnaires indicators (including gender division) were calculated using Spearman's rank correlation coefficient. On the other hand, intergroup differences were calculated using Kruskal-Wallis 1-way ANOVA. A level of statistical significance of $\mathrm{p} \leq 0.05$ was adopted.

\section{RESULTS}

Our analysis revealed that there was no correlation between age and NDI scores in females $(r=0.027)$. In contrast, in males, a correlation coefficient was weak $(r=0.202)$ but statistically significant $(p \leq 0.05)$. With regard to the lumbar spine, statistically significant $(\mathrm{p} \leq 0.05)$ but weak correlations were reported between: age and ODI, in females $(r=0.219)$ and in males $(r=0.180)$. No associations between the body mass index (BMI) and the degree of disability of the cervical and lumbar spine were found, and the correlation coefficients were: $r=0.044$ and $r=0.096$ for women, vs. $r=0.041$ and $r=0.002$ for men.

Percentages of the study participants (female vs. male), according to a degree of disability of the spine are presented in the Table 1 . The prevalence of at least mild back pain during the examination in cervical region was exhibited by $43 \%$ and $47.4 \%$ women and men, respectively. As far as the lumbar area is concerned, everyone in the study population suffered from at least mild pain that lasted for at least 3 months during the last year prior the examination (Table 1).

We have also examined physical activity indicators (WI, SI, LTI, and HPA) among female and male respondents, and the differences due to the degree of disability of the spine are summarized in the Table 2. No differences between mentioned indicators and the NDI were found. Differences were significant only for the ODI among women (Table 2).

We report that the NDI scores did not differ, depending on the activity indicators. In the case of women, disability related to back pain in the lumbar area (independent variable) had a negative impact on the indicators of their activity during work (WI), sports (SI), and leisure time (LTI) (dependent variables) (Figure 1). In the case of men, the ODI scores did not differ based on any of the analyzed activity indicators.

\section{DISCUSSION}

School teachers represent an occupational group, in which the prevalence of musculoskeletal disorders, in different body sites, appears to be high, due to

Table 1. The degree of disability of the spine in cervical and lumbar area in both gender

Tabela 1. Stopień niesprawności kręgosłupa w odcinku szyjnym i lędźwiowym odcinku zależnie od płci

\begin{tabular}{|c|c|c|c|c|c|c|}
\hline $\begin{array}{l}\text { Degree of disability } \\
\text { of the spine } \\
\text { Stopień niesprawności } \\
\text { kręgosłupa }\end{array}$ & \multicolumn{3}{|c|}{ NDI } & \multicolumn{3}{|c|}{ ODI } \\
\hline 0 & 57.0 & 52.6 & 0.3063 & - & - & - \\
\hline 1 & 34.3 & 37.7 & 0.3967 & 86.0 & 87.1 & 0.7132 \\
\hline 3 & 0.6 & 2.6 & $0.0155^{\star}$ & 1.2 & 2.6 & 0.1726 \\
\hline
\end{tabular}

0 - lack of dysfunction (Neck Disability Index - NDI) or minimal (Oswestry Disability Index - ODI) / brak (wskaźnik niepełnosprawności Oswestry - NDI) lub minimalna (szyjny indeks niepełnosprawności - ODI) dysfunkcja, 1 - mild (NDI) or moderate (ODI) / łagodna (NDI) lub umiarkowana (ODI), 2 - moderate (NDI) or moderate to serious (ODI) / umiarkowana (NDI) lub pomiędzy umiarkowaną a poważną (ODI), 3 - severe (NDI) or serious (ODI) / ciężka (NDI) lub poważna (ODI).

${ }^{*} \mathrm{p} \leq 0.05$ - statistically significant / istotne statystycznie. 
Table 2. Physical activity indicators among female and male respondents showing differences based on the degree of disability of the spine

Tabela 2. Wskaźniki aktywności fizycznej i różnice ze względu na poziom niesprawności kręgosłupa

\begin{tabular}{|c|c|c|c|c|c|c|}
\hline \multirow{2}{*}{$\begin{array}{c}\text { Activity indicator } \\
\text { Wskaźnik aktywności }\end{array}$} & \multicolumn{2}{|c|}{$\begin{array}{c}\text { Basic statistics } \\
\text { Statystyki podstawowe }\end{array}$} & \multicolumn{2}{|c|}{ NDI } & \multicolumn{2}{|c|}{ ODI } \\
\hline & $\mathrm{M} \pm \mathrm{SD}$ & $\mathrm{Me}$ & $\mathrm{Chi}^{2}$ & $\mathrm{p}$ & $\mathrm{Chi}^{2}$ & $\mathrm{p}$ \\
\hline \multicolumn{7}{|l|}{ Work indicator / Wskaźnik pracy (WI) } \\
\hline females / kobiety & $2.65 \pm 0.41$ & 2.63 & 1.50 & 0.6821 & 7.95 & $0.0188^{\star}$ \\
\hline \multicolumn{7}{|l|}{ Sport indicator / Wskaźnik sportu (SI) } \\
\hline females / kobiety & $2.49 \pm 3.46$ & 2.25 & 2.26 & 0.5208 & 7.26 & $0.0264^{*}$ \\
\hline males / mężczyźni & $2.69 \pm 0.94$ & 2.50 & 2.53 & 0.4696 & 4.66 & 0.0974 \\
\hline \multicolumn{7}{|c|}{ Leisure-time indicator / Wskaźnik czasu wolnego (LTI) } \\
\hline \multicolumn{7}{|c|}{ Habitual physical activity / Wskaźnik sumaryczny } \\
\hline females / kobiety & $8.28 \pm 1.26$ & 8.25 & 1.65 & 0.6473 & 5.99 & $0.0502^{*}$ \\
\hline males / mężczyźni & $8.51 \pm 1.72$ & 8.38 & 3.14 & 0.3713 & 5.42 & 0.0664 \\
\hline
\end{tabular}

M - mean / średnia, SD - standard deviation / odchylenie standardowe, Me - median / mediana, Chi ${ }^{2}$ - Chi-squared test / test Chi-kwadrat.

Other abbreviations as in Table 1 / Inne objaśnienia jak w tabeli 1.
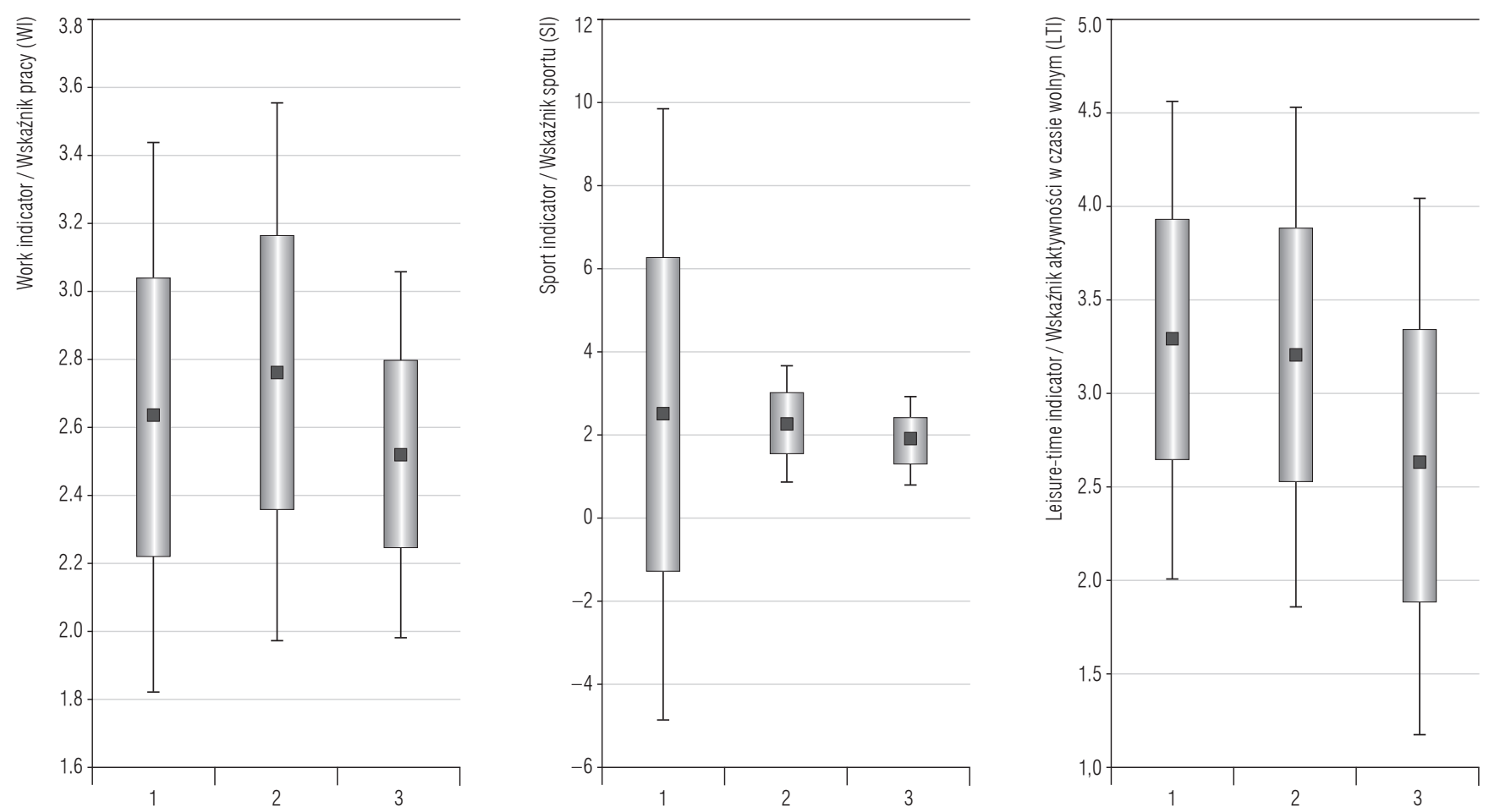

$\square$ 25-75\% $\square$ median / mediana I min.-maks. / min.- max

Oswestry disability index / Wskaźnik niepełnosprawności Oswestry (ODI)

Fig. 1. Females - the degree of disability of the lumbar spine and the activity level

Ryc. 1. Kobiety - stopień niesprawności kręgosłupa lędźwiowego a wskaźniki aktywności 
multifactorial causes, which may be, to some degree, prevented [14].

In particular, long-term awkward positions at work, and frequent working at computer stations are examples of risk factors, predisposing to various occupational disorders of the upper extremities, neck and back [15].

In the case of aetiopathogenesis of back and neck pain, many psychosocial factors, including stress or burnout syndrome, may also play an important role $[16,17]$. Our cross-sectional study, conducted among professionally active teachers, explores the prevalence and severity of back and neck pain, and its relationship with demographic variables and physical activity. Our data analysis indicates that there were no participants with severe or total disability of the cervical spine, and the lumbar spine, based on the NDI and ODI scales, respectively. Nevertheless, there is a problem, confirmed by the fact that $43 \%$ of women and $47 \%$ of men suffer from spinal dysfunctions related to the cervical area (mild, moderate, and severe), and that $14 \%$ of women and almost $13 \%$ of men experience symptoms of pain or discomfort in the lumbar area (moderate and severe disability) (Table 1). In our study, no differences related to sex were found, except for a severe degree of the cervical spine disability, which was higher for men. Possible higher predispositions toward pain in the cervical spine area in the case of men would require confirmation by other studies, and further investigation of their causes. Studies performed in different countries also indicate the significant proportion of pain in cervical and lumbar spine among teachers [18].

Our analysis did not report associations between the BMI and disability of the spine (in both areas). The association between obesity and the LBP has been investigated by many researchers but the results remain inconclusive. On the one hand, it appears that obesity is a predisposing factor to the more prevalent LBP. However, the results of several studies are controversial, and this hypothesis requires examination in further studies $[19,20]$.

Our study results did not show a correlation between age and cervical spine disability for women. Such correlations, reported in other cases, even weak (that may be explained by the participants' age), indicate that the age is an independent prognostic factor of the prevalence of the LBP [21].

The final association, analyzed in our study, is related to the impact of cervical and lumbar spine disability on the level of physical activity. Our findings indicate that the degree of cervical spine disability did not cause differences among participants, in any type of the analyzed activities. In addition, there was no difference in the entire group, and similarly, no differences in either women or men (Table 2). These results concur with a recent review of the literature that indicates that the pain in the cervical spine may have a stronger link with psychosocial factors than with physical activity or habitual position, typically assumed, during the performance of daily activities [22].

We report some differences with regard to the lumbar spine among women, for whom we have documented statistically significant differences related to the WI, SI, and LTI. However, we did not determine differences relevant to global activity.

Unequivocal results with regard to the WI may be explained by a substantial discrepancy of the assessment of physical exertion at work. Our findings related to the SI and LTI appear to be clear and consistent - with an increased level of spine disability, the SI and LTI were decreased for women (Figure 1). In the case of men, the spine disability did not cause a difference in any type of physical activity. A connection between physical activity and lumbar spine disability, based on our cross-sectional study design, is controversial, since an association of cause and result cannot be determined.

Swedish investigators, based on population studies of subjects with diversified activity levels, linked the prevalence of chronic back pain with hard physical workload, limited recreational activity, connected with low educational level, and tobacco smoking [23]. Similarly, associations between educational level and recreational activity have been confirmed by a study of inhabitants of Katowice (a large industrial town in Poland), conducted among physical workers, operators, teachers, scientists, and service workers. The first 2 groups linked their physical activity mostly with their occupational activity, and the remaining 3 groups (including teachers) related their physical activity to both leisure time and professional duties [24].

In light of our findings focused on teachers, as a homogeneous professional group (with regard to education, social status, and a relatively low level of physical exertion necessary to perform this job), it is very concerning that they report such a low level of recreational activity, including sports (Table 2). Unfortunately, this sedentary lifestyle, characteristic of this profession, may contribute to back pain, and lead to the retirement of school teachers due to ill health. 
For instance, in Scotland, this problem affects about $18 \%$ of teachers [25], and in Ireland about $10 \%$ [26]. In this aspect, our study results are convergent with observational research findings of Brito et al. that indicate the low level of physical activity among educators [27]. Other authors claim that the positive evaluation of the quality of life correlates with the high level of physical activity [28].

Also, it should be noted that non-ergonomic positions at work have a negative impact on the LBP, particularly among special education teachers of severely handicapped students [29].

Moreover, global activity illustrated by the HPA index was near its lower level, based on scores achieved on disability scales (Table 2). Nevertheless, with the increase of the lumbar spine disability level, there is a tendency towards a limitation of physical activity among female teachers, both in occupational and personal domains. This may contribute to a decrease in their quality of life in general [30].

Our study had some limitations. For instance, information about neck and back pain symptoms and related physical activity factors were self-reported by the respondents (this was the only method available to us, and we were unable to eliminate the possibility of recall bias, which may lead to some inaccurate answers). Moreover, according to the design of this cross-sectional study, only correlations may be established; however, no inferences of causality may be made. Nevertheless, our data underlines that school teachers often suffer from lower back pain, and there is a great need to conduct further prospective research studies in this field. Considering the teachers' workload and daily stress, it is imperative to invent and implement some effective preventive and interventional action plans in the near future.

\section{CONCLUSIONS}

1. The study findings confirm that the pain in cervical and lumbar area represents a serious occupational problem in a large percentage of the population of school teachers.

2. The body mass index is not related to the back and neck pain, while age seems to be a prognostic factor of pain only in the lumbar area.

3. The limitation of physical activity leads to a more frequent back pain.

4. There is a need for implementation of the programme that promotes healthy lifestyle with the special consideration of the physical activity for teachers.

\section{What this paper adds -}

\section{an overview of the whole article}

1. This study analyzed the prevalence and severity of back and neck pain, based on demographic variables, and the relationship with physical activity among teachers.

2. Our study has revealed that the teachers' age appears to be a prognostic factor, while no associations between the body mass index (BMI) and low back pain (LBP) have been shown.

3. Increase in disability due to the LBP has a negative impact on physical activity, especially in female teachers, and thus, emphasis on prevention and application of ergonomic principles are of great importance among teachers.

\section{REFERENCES}

1. Myśliwiec A, Saulicz E, Kuszewski M, Kokosz M, Wolny T. Assessment of the influence of saunders traction and transcutaneous electrical nerve stimulation on hand grip force in patients with neck pain. Ortop Traumatol Rehabil. 2011;1(6):37-44, http://dx.doi. org/10.5604/15093492.933786.

2. European Agency for Safety and Health at Work. [Information regarding musculoskeletal disorders related to work]. FACTS. 2007 [cited 2014 Dec 11];71. Available from: http:// osha.europa.eu/pl/publications/factsheets/71. Polish.

3. Karczewicz E, Sikora A. [Information about absenteeism persons insured ZUS in 2013 and the first half of 2014] [Internet]. Warszawa: Zakład Ubezpieczeń Społecznych, Departament Statystyki i Prognoz Aktuarialnych; 2014 [cited 2014 Dec 12]. Available from: http://www.zus.pl/files/ Absencja\%20chorobowa\%20w\%202012\%20roku\%20.pdf. Polish.

4. Hamberg-van Reenen HH, Ariens GAM, Blatter BM, Twisk JWR, van Mechelen W, Bongers PM. Physical capacity in relation to low back, neck, or shoulder pain in a working population. Occup Environ Med. 2006;63(6): 371-7, http://dx.doi.org/10.1136/oem.2006.026914.

5. Woynarowska-Sołdan M, Tabak I. [Health enhancing behaviors of teachers and other school staff]. Med Pr. 2013;64(5):659-70, http://dx.doi.org/10.13075/mp.5893. 2013.0065. Polish.

6. Polak M. [Teachers in Poland in 2013] [cited 2014 Dec 12]. Available from: http://www.edunews.pl/edytoriale/2418nauczyciele-w-polsce-2013. Polish.

7. Vernon H, Mior S. The neck disability index: A study of reliability and validity. J Manipulative Physiol Ther. 1991;14(7):409-15. 
8. Cleland JA, Fritz JM, Whitman JM, Palmer JA. The reliability and construct validity of the neck disability index and patient specific functional scale in patients with cervical radiculopathy. Spine. 2006;31(5):598-602, http://dx.doi.org/10.1097/01.brs.0000201241.90914.22.

9. Murphy DR, Lopez M. Neck and back pain specific outcome assessment questionnaires in the Spanish language: A systematic literature review. Spine J. 2013;13(11): 1667-4, http://dx.doi.org/10.1016/j.spinee.2013.08.046.

10. Fairbank J, Pynsent PB. The Oswestry disability index. Spine. 2000;22(25):2940-53, http://dx.doi.org/10.1097/00 007632-200011150-00017.

11. Davidson M, Keating JA. Comparison of five low back disability questionnaires: Reliability and responsiveness. Phys Ther. 2002;82:8-24.

12. Baecke JAH, Burema J, Frijters JER. A short questionnaire for the measurement of habitual physical activity in epidemiological studies. Am J Clin Nutr. 1982;36:936-42.

13. Philippaerts RM, Westerterp KR, Lefevre J. Comparison of two questionnaires with a tri-axial accelerometer to assess physical activity patterns. Int J Sports Med. 2001;22(1):34-9, http://dx.doi.org/10.1055/s-2001-11359.

14. Erick PN, Smith DR. A systematic review of musculoskeletal disorders among school teachers. BMC Musculoskelet Disord. 2011;17(12):260, http://dx.doi. org/10.1186/1471-2474-12-260.

15. Zejda JE, Bugajska J, Kowalska M, Krzych L, Mieszkowska M, Brozek G, et al. [Upper extremities, neck and back symptoms in office employees working at computer stations]. Med Pr. 2009;60(5):359-67. Polish.

16. Olaya-Contreras P, Styf J. Biopsychosocial function analyses changes the assessment of the ability to work in patients on long-term sick-leave due to chronic musculoskeletal pain: The role of undiagnosed mental health comorbidity. Scand J Public Health. 2013;41(3):247-55, http://dx.doi.org/10.1177/1403494812473380.

17. Poraj G. [Personality as a teacher's burnout predictor]. Med Pr. 2009;60(4):273-82. Polish.

18. Pengying Y, Fengying L, Liping L. Neck/shoulder pain and low back pain among school teachers in China, prevalence and risk factors. BMC Public Health. 2012;12:789, http://dx.doi.org/10.1186/1471-2458-12-789.

19. Mirtz TA, Greene L. Is obesity a risk factor for low back pain? An example of using the evidence to answer a cli- nical question. Chiropr Osteopat. 2005;13:2, http://dx. doi.org/10.1186/1746-1340-13-2.

20. Shiri R, Karppinen J, Leino-Arjas P, Solovieva S, Viikari-Juntura E. The association between obesity and low back pain: A meta-analysis. Am J Epidemiol. 2010;171(2): 135-54, http://dx.doi.org/10.1093/aje/kwp356.

21. Andreson JA. Epidemiological aspects of back pain. J Soc Occup Med. 1986;36:90-4, http://dx.doi.org/10. 1093/occmed/36.3.90.

22. Diepenmaat ACM, van der Wal MF, de Vet HCW, Hirasing RA. Neck/shoulder, low back, and arm pain in relation to computer use, physical activity, stress, and depression among dutch adolescents. Pediatrics. 2006;117(2): 412-6, http://dx.doi.org/10.1542/peds.2004-2766.

23. Björck-van Dijken C, Fjellman-Wiklund A, Hildingsson C. Low back pain, lifestyle factors and physical activity: A population based-study. J Rehabil Med. 2008;40(10): 864-9, http://dx.doi.org/10.2340/16501977-0273.

24. Puciato D, Rozpara M, Mynarski W, Łoś A, Królikowska B. [Physical activity of adult residents of Katowice and selected determinants of their occupational status and socio-economic characteristics]. Med Pr. 2013;64(5): 649-57. Polish.

25. Hobson J. Learning from teachers. Occup Med (Lond). 2001;51:297-8, http://dx.doi.org/10.1093/occmed/51.5.297.

26. Maguire M, O'Connell T. Ill-health retirement of school teachers in the Republic of Ireland. Occup Med (Oxford). 2007;57(3):191-3, http://dx.doi.org/10.1093/occmed/kqm001.

27. Brito WF, Santos CL, Marcolongo A, Campos MD, Bocalini DS, Antonio EL, et al. Physical activity levels in public school teachers. Rev Saude Publica. 2012;46(1):104-9, http://dx.doi.org/10.1590/S0034-89102012000100013.

28. Da Cruz Ramos de Araujo C, Coutinho do Azevedo Guimarães A, Meyer C, Boing L, Ramos Mde O, Souza Mde $\mathrm{C}$, et al. [Influence of age on the perception of finitude and quality of life]. Ciência Saúde Coletiva. 2013;18(9):2497-505, http://dx.doi.org/10.1590/S1413-81 232013000900003. Portuguese.

29. Wong KC, Lee RY, Yeung SS. The association between back pain and trunk posture of workers in a special school for the severe handicaps. BMC Musculoskelet Disord. 2009; 29(10):10-43, http://dx.doi.org/10.1186/1471-2474-10-43.

30. Soysal M, Kara B, Arda MN. Assessment of physical activity in patients with chronic low back or neck pain. Turk Neurosurg. 2013;23(1):75-80.

\footnotetext{
This work is available in Open Access model and licensed under a Creative Commons Attribution-NonCommercial 3.0 Poland License / Ten utwór jest dostępny w modelu open access na licencji Creative Commons Uznanie autorstwa - Użycie niekomercyjne 3.0 Polska - http://creativecommons.org/ licenses/by-nc/3.0/pl.
} 